\title{
Bone Problems Caused by The Deficiency of Calcium and Phosphorus in the Feeding of Broilers
}

\author{
Matheus Vinícius Abadia Ventura*1 and Rafael Matias da Silva ${ }^{2}$ \\ ${ }^{1}$ Goiano Federal Institute, Brazil \\ ${ }^{2}$ Goiano Federal Institute, Brazil
}

*Corresponding author: Matheus Vinícius Abadia Ventura, Postgraduate in Agricultural Sciences, Goiano Federal Institute, Rio Verde, Brazil

\begin{abstract}
ARTICLE INFO
Received: March 25, 2019

Published: April 01, 2019

Citation: Matheus Vinícius Abadia Ventura, Rafael Matias da Silva. Bone Problems Caused by The Deficiency of Calcium and Phosphorus in the Feeding of Broilers. Biomed J Sci \& Tech Res 16(4)2019. BJSTR. MS.ID.002886.
\end{abstract}

Keywords: Productivity; Minerals; Deformities; Chicken

\section{ABSTRACT}

One major concern for poultry producers is the productivity of chickens, with the lack or excess of minerals, this productivity is compromised and cannot be achieved to the maximum, giving damage to the producer. A descriptive study was carried out, identifying and checking deformities alleged techniques that can be applied to resolve these problems. Calcium and Phosphorus are essential minerals for the chickens, and which are essential for various functions and their bone development. The study of these minerals and their contribution to the broiler is of great importance and may be monitored and analyzed its development, identifying deficiencies and correct them with them. The appropriate rate of minerals to the broiler is crucial in their development, seeking to combat bone abnormalities with alternatives and techniques in their growth.

\section{Introduction}

Nowadays, Brazil maintains a position of great importance in the world scenario in the production of broilers, and in 2004 Brazil became the largest exporter and also the third largest in the world. This is due to the conquest of the foreign market, which recently Brazil broke a new record where it recorded in the last 12 months a cluster of 3,770 million tons (UBABEF, 2013). Even with the world crisis in 2009 the production of chicken meat was high. According to the surveys, the world poultry industry produced 71.715 million tons, about $0.39 \%$ more than the previous year. Still with a lowprice appearance, the data indicates a positive behavior. Especially when it refers to an era of international recovery (UBA, 2009). In recent years, the concern of the chicken-producing industries revolves around its high productivity where, because of this, they are having problems with the appearance of brittle bones and deformities in their production, this is often due to the lack of calcium and phosphorus in feed for broilers, since these minerals are important for the bone development of chickens. The role of calcium and phosphorus is important for chickens' nutrition and their deficiency precludes peak performance during the growth period. For this to occur it is necessary to balance calcium and phosphorus in the feed and nutrition of the chickens, causing the industries to make a profitable return on their production [1].

The importance of calcium and phosphorus is significant, contributing to the development of chickens, helping in nutrition and actively participating in bone development. In addition to calcium, phosphorus participates in numerous functions in the body, being involved in various metabolic reactions, being responsible together with calcium for the formation and maintenance of bones [2]. Chicken performance cannot be demanded when the minerals are not sufficient, thus giving damage like brittle bones or poor productivity. In spite of the increasing demand, it is verified that the majority of researches have been in the area of breeding, there is a shortage in researches that evaluate nutritional requirements of these chickens, being necessary to do the supplementation for a better growth and development. Calcium and phosphorus are closely associated elements in animal metabolism, often 
combined with one another, so that the lack of one in the diet limits the performance of the chickens [3]. The search for a genetic improvement is a very good option, but I believe that the value invested for this improvement is much higher than an investment in improving nutritional requirements, balancing the nutrients, may require a higher performance and productivity of the chicken, this way, giving a positive return.

\section{Importance of Calcium and Phosphorus}

Calcium is the most intense mineral in the body of chickens. Being one of the main constituents of bones, as it plays an important role in the balance of cellular functions of nervous and muscular tissues, as well as of hormonal activities and also of blood coagulation [3]. Supplementation is essential for healthy growth and development, but deficiency of calcium and phosphorus in this supplementation may influence and limit bone growth in broilers [3]. Phosphorus deficiency can result in bone breakage or defects during processing, causing the carcass to be declassified [4]. These defects can interfere in performance and also in skeletal development, causing losses to their producers in relation to their production beyond these problems, weak feathers are repeatedly associated with reduced intake of food affecting chick weight gain [5]. In addition to calcium in bone maintenance and development, it is also important because it assists growth, egg shell formation, blood clotting, involvement with secretion of different hormones, and transmission of nerve impulses. Therefore, the need to get as close as possible to the calcium balance, being that its influence mainly affects the productivity of the chickens [6].

Calcium and phosphorus are closely associated elements in animal metabolism, often combined with one another, so that the lack of one in the diet limits the performance of the chickens [3]. When broilers are fed diets with deficient levels of calcium and phosphorus, they are able to demonstrate a certain ability to adapt to moderate deficiency, increasing the absorption of these minerals and the hydrolysis of Phyto phosphorus (YAN). The chicken will always adapt to feed to it, but will never give its highest performance, thus giving damage to the producer. Therefore, there is a need for balanced use of calcium in feed, so that there is a greater requirement of chicken in relation to food products, which in the future will be marketed.

\section{Bone Development}

Bone, a metabolically active tissue, composed of several cellular elements. It works as a mechanical support to the body where it is responsible for the sustenance of the animals, in addition, it serves as a metabolic reserve of calcium and phosphorus [3]. Adequate bone mineralization is of fundamental importance in cutting chicken, since muscle development is dependent on good bone support and is necessary for the proper functioning of the locomotor system. Chicken with deficiencies in bone development may suffer fractures during picking, transport and slaughtering, resulting in heavy losses due to condemnation of carcasses in the slaughterhouse [7] (apud GABRIELA). The main reserve of calcium in the body is the bone, it is composed of a heterogeneous tissue that has the function of supporting the entire weight of the animal. In addition, there is also an organic structure composed of fibres, mainly collagen, through which the mineral phase which is composed of hydroxyapatite (BAYNES \& DOMINICZAK, 2000 p. 36) [8]. The bone development of the chickens is deeply associated with the growth of the animals with that the bone tissue develops and grows in proportion as it is being used and can even atrophy when in disuse. It acts as a reserve of calcium and phosphorus where it may be required of the animal when there are changes in homeostasis (KUSSAKAWA \& FARIA, 1998).

\section{Bone Deformities}

Many causes of bone deformities in the bone tissue of chickens have been discovered since 1930, among them are nutrients, genetics, pathogens. Another factor that is affecting successively are the management practices that can directly interfere in the growth and development of the bone structure [9]. In poultry production there are two most relevant categories related to bone deformities, with tibial dyschondroplasia (TD), which affects chickens in the early stages of growth and structural problems, leading to deformities and distortions of long bones, especially in the final phase of growth (Barbosa et al., 2010 p. 7). The poultry industry is currently facing a high percentage of bone tissue deformities, mainly due to genetic selection carried out with the aim of increasing the growth rate of the animals [10]. Leg problems may be associated with the genetic characteristics of the animals, which present very rapid muscle growth and accumulation, with bone tissue developing at a slower rate [11]. Bone abnormalities found in fast-growing broiler chickens have in recent years been one of the most damaging issues for the poultry industry. These diseases, besides compromising the welfare of the chicken, reduce the production and quality of the products originated.

Many symptoms resulting from bone abnormalities are not clinically visible, making it difficult to quantify the damage (FALCONE). Research should closely analyse these abnormalities, because they bring losses to the producer, influencing the production and quality, and investment is necessary for them, since they are often not visible. The problems of deformity of the legs may be a consequence of the uneven growth of the growth plate and the abnormal position of the legs, but this problem probably can result from the tension of the muscle where the bones are pulled out of the alignment (JULIAN, apud ANDRÉIA). Follow-up is always necessary and nutrient corrections are critical if performance is to be required and productivity is a desirable return. Bone chondrodystrophy refers in turn to a generalized disorder in the growth zone of long bones, but mineralization and lateral growth (diameter) are apparently normal in chicken, ie shortening of the long bones and thickening of the tibio-tarsal joint, resulting in a variable 
degree of angulation (valgus-varus deformation), and the lack of chondrocytes due to hypertrophy is observed in the proliferation zone and, therefore, the receipt of nutrients by diffusion denotes inadequate nutrition or deficiencies in minerals, especially calcium and its interactions metabolic anomalies of great impact on the productive yield of broiler (THORP, TARDIN) [12]. With affected bone development, yield, performance and productivity are small when corrected with minerals, they increase considerably. While osteoporosis has not been considered a major disease in broilers, there is evidence that some strains show decreased mineralization and increased bone porosity [13].

\section{Nutrition and Feeding of Broilers}

Nutrition plays a key role in obtaining high quality bone tissue. Among the nutrients, calcium and phosphorus are the main formers of the mineral matrix, contributing with 95\% [14]. In chicken, calcium is the mineral found in the greatest quantity, being present almost entirely (99\%) in the bone tissue, being required in quantity greater than any other mineral [6]. Inequality of cations and anions in the diet may have influenced the increase of leg problems in broilers, since they are fast-growing chicken. Several alterations of this stability can generate damages in the performance of the chickens [15]. The effects of different cations and anions on the incidence of tibial dyschondroplasia are dependent on each other, showing the importance of dietary electrolyte balance in the determination of this leg problem [16]. Being that for the producer, the profitable part and the well-being of the chicken for that to be reached are main factors. The basic constitution of poultry feed is made with soybean and corn, but they have insufficient levels to compose the requirements of calcium and phosphorus, so it is important to make a calcium supplementation that meets these and requirements, noting that calcium origin can influence the performance of chickens [6]. The chickens adapt to the feed offered to them, but if it is deficient in minerals, it cannot show its productivity to the maximum.

\section{Materials and Methods}

A descriptive study was carried out in order to collect data and verify existing hypotheses, analysing the minerals, identifying the deformities and verifying supposed techniques that can be applied to solve these problems. The information was obtained through articles from scientific journals and theses of researchers, aiming at the identification and analysis of the data as a collection tool, the bibliographic research, using criteria that addressed the need of these minerals for the chickens, besides identifying deformities and analyse techniques that would contribute to the producer and poultry industry. Then, using scientific theses and journals from researchers that showed the importance of a balanced feed for the chickens, so that it is extracted from it, the greater development in the growth and performance in the production, analysing the possible deformities that can appear, besides showing the importance of calcium and phosphorus for chickens.

\section{Results and Discussion}

According to the literature review and analysis of the information it was possible to observe the importance of making a diet based on calcium and phosphorus, as they are important for healthy bone development avoiding porosities deformities and also problems of nozzles. Adequate mineral supplementation during the growth phase will result in proper development, especially in bones, where most phosphorus and calcium are found. The main symptom of deficiency of calcium and phosphorus is, in addition to a lower performance of the birds, the appearance of bones and fragile beaks; however, excess calcium can act as an antagonist, hindering the absorption of some minerals (BARROS). Adequate bone mineralization is essential in the poultry industry, as muscle development is dependent on good bone support and is necessary for the proper functioning of the locomotor system (ARAÚJO).

One of the possible ways to combat bone anomalies (and other problems related to the sudden increase in the rate of metabolic activity of broiler chickens) would be to slow the growth rate, especially in the period when it occurs more rapidly: in the beginning of the creation cycle. One of the techniques used to decelerate the growth rate of poultry, or rather the most frequently used one, is the food restriction, which consists of reducing for a period of time the food ingested by the animal, either in its quantity (quantitative restriction) or in its composition (qualitative restriction) [17]. But for the producer, if this care is not taken, especially in the food, besides the chicken malaise, it will not achieve the maximum in production that the chicken can convert, therefore, a balanced diet and a follow-up in the process of growth and development will be repaying in profits to the producers in the end and will keep the poultry industry at a high level of production [18-22].

\section{Conclusion}

It is concluded that the mineralization of broilers chickens and of extreme importance, because the bones need calcium and phosphorus for their development. In addition, these minerals are necessary because they aid in the metabolism of chickens, however when these minerals are not used properly in the feeding the chickens can suffer bone deformities or malformation causing damages to the producers and industries.

\section{References}

1. Vargas Junior JGD, Albino LFT, Rostagno HS, Gomes PC, Carvalho DCO, et al. (2004) Nutritional levels of calcium and available phosphorus for white-egg pullets and brown-egg pullets from 13 to 20 weeks of age. Revista Brasileira de Zootecnia 33 (4): 1263-1273.

2. Trevizan L (2003) Phosphorus in the animal body: importance and deficiency. Santa Maria: UFRGS, p. 54.

3. Macari M, Furlan, Elisabeth Gonzales L (2002) Fisiologia aviária aplicada a frangos de corte. Jaboticabal, FUNEP/UNESP, pp. 375

4. Brenes A, Viveros A, Arija I, Centeno C, Pizarro M, et al. (2003) The effect of citric acid and microbial phytase on mineral utilization in broiler chicks. Animal Feed Science and Technology 110(1-4): 201-219. 
5. Onyango EM, Hester PY, StroshineR, Adeola O (2003) Bone densitometry as an indicator of percentage tibia ash in broiler chicks fed varying dietary calcium and phosphorus levels. Poultry Science 82(11): 17871791.

6. Sá LM, Gomes PC, Albino LFT, Rostagno HS, D’Agostini P (2004) Calcium requirement and bioavailability of some feedstuffs for broiler chicks from 1 to 21 days old. Revista Brasileira de Zootecnia 33(1): 157-168.

7. Schoulten NA, Teixeira AS, Freitas RTFD, Bertechini AG, Conte AJ, et al (2003) Levels of calcium in broiler diets supplemented with phytase in the initial phase. Revista Brasileira de Zootecnia 32(5): 1190-1197.

8. Barbosa AA, de Moraes GHK, de Almeida R, Torres DTDCR, de Souza Rodrigues CET, et al. (2010) Avaliação da qualidade óssea mediante parâmetros morfométricos, bioquímicos e biomecânicos em frangos de corte. R Bras Zootec 39(4): 772-778.

9. Cook ME (2000) Skeletal deformities and their causes: introduction Poultry Science 79(7): 982-984.

10. Velleman SG (2000) The role of the extracellular matrix in skeletal development. Poultry science 79(7): 985-989.

11. Silva FAD, Moraes GHKD, Rodrigues ACP, Oliveira MGDA, Rostagn HS, et al. (2001) Effects of L-Glutamic Acid and Vitamin D3 on Performance and Incidence of Leg Problems of Broilers Chicks. Revista Brasileira de Zootecnia, 30(6): 2059-2066.

12. Barbosa Muniz E, Martins Varela de Arruda A, Fassani EJ, Soares Teixeira A, Sales Pereira E (2007) Avaliação de fontes de cálcio para frangos de corte. Revista caatinga 20(1): 5-14.

13. Williams B, Waddington D, Solomon S, Farquharson C (2000) Dietary effects on bone quality and turnover, and $\mathrm{Ca}$ and $\mathrm{P}$ metabolism in chickens. Research in veterinary science 69(1): 81-87.

\section{ISSN: 2574-1241}

DOI: 10.26717/BJSTR.2019.16.002886

Matheus Vinícius Abadia V. Biomed J Sci \& Tech Res

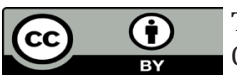

This work is licensed under Creative Commons Attribution 4.0 License

Submission Link: https://biomedres.us/submit-manuscript.php
14. Rath NC, Huff GR, Huff WE, Balog JM (2000) Factors regulating bone maturity and strength in poultry. Poultry Science 79(7): 1024-1032.

15. Franco JRG, Murakami AE, Sakamoto MI, Martins EN, Moreira I, et al. (2004) Effect of ionophores and acid-base balance on performance and incidence of tibial dyschondroplasia in 21-d old broiler chicks. Revista Brasileira de Zootecnia 33(1): 135-145.

16. Murakami AE (2000) Electrolyte balance of the diet and its influence on the development of broiler bones. In Apinco Conference on Poultry Science and Technology. Campinas: APINCO Foundation for Poultry Science and Technology, p. 33-66.

17. Bruno LDG (2002) Desenvolvimento ósseo em frangos: Influência da restrição alimentar e da temperatura ambiente p. 77.

18. Araújo GM (2009) Anionic and cationic variation of the diet on the bony characteristics of broilers: resistance to breaking, mineral and organic composition. 03f. Dissertation (master's in animal science) - Federal University of Mato Grosso, Cuiabá.

19. Kussakawa KCK, de Faria HG (1998) Discondroplastia Tibial em Frangos de Corte: Aspectos Nutricionais. Arquivos de Ciências da Saúde da UNIPAR 2(3)

20. Oliveira AFG (2006) Estudo do padrão de crescimento ósseo em frangos de corte de diferentes grupos genéticos criados em duas densidades populacionais. Dissertação (Mestrado) - Universidade Estadual de Maringá, Maringá.

21. Uba (2009) Brazilian Union of Poultry. Technical Standard for Integrated Chicken Production. Coordinators: Mendes, A. A; Paz, I. C. L. - São Paulo: Brazilian Poultry Union, p. 64.

22. Amoroso L (2009) Respostas densitometrias, morfofisiológicas e desempenho de frangos de corte tratados com água filtrada e não filtrada. Repssitorio Institucional UNESP.

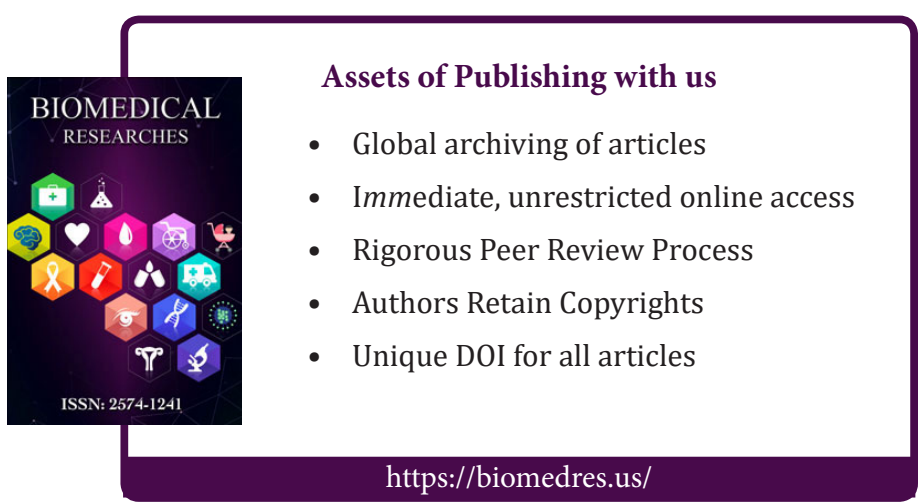

